\title{
PENYUSUNAN MODEL PENDUGA VOLUME POHON JENIS JELUTUNG RAWA (Dyera polyphylla (Miq) V. Steenis)
}

\author{
(Development of estimating tree volume equations for Jelutung Rawa (Dyera polyphylla)) \\ Muhammad Abdul Qirom ${ }^{1}$ dan Supriyadi ${ }^{2}$ \\ ${ }^{1,2}$ Balai Penelitian Kehutanan Banjarbaru \\ Jl. Ahmad Yani Km 28,7 Landasan Ulin, Banjarbaru, Telp./Fax. 0511-4707872 \\ ${ }^{1}$ Email:qirom_ma@yahoo.co.id
}

Naskah masuk : 17 November 2011; Naskah diterima : 28 Agustus 2012

\begin{abstract}
The development of of Dyera polyphylla trees requires complete information on the estimated yield. The estimated yield or volume can be obtained by using an estimating equation for the tree volume. The objectives was to obtain of the best estimation models for the total and merchantable volumes of $\underline{D}$. polyphylla trees. The volume estimation models were formulated using 96 selected tree samples representing the whole stand populations. Sample trees were measured using Spiegel Relascop Bitterlich (SRB). The estimator models tested consist of linear and non-linear models with a single variable (diameter) and double variables (diameter and height of the tree). The results of this study indicated that diameter as the single variable can be used to formulate an estimator model for both the total and merchantable volumes of trees. However, the addition of the height variable into the model is still needed. The estimation models of tree volumes with two variables (diameters and heights) were used to obtain a standard volume table. The determination coefficient rose less than $2 \%$ compared to the model with the diameter variable. The best model of tree volume estimators with either one or two variables has high coefficient $(>80 \%)$ of determination $\left(R^{2}\right)$. The best models of estimating total tree volume are 1) with the use of diameter as a single variable: Ln Volume ) ) 7.9444 ) 2.1952)* Ln )Diameter)), and 2) with the use of diameter and height as double variables: Volume $=2.4081 * 10^{-4} *\left(\text { Diameter }^{2} \text {. Height }\right)^{0.80871}$. The best models to estimate the volume of merchantable trees are 1) with the use of diameter variable: Ln Volume $=8.2598+(2.2843) *($ Ln(Diameter $))$, and 2$)$ with the use of diameter and height as the variables: Ln Volume $=9.0589+(1.8958) *($ Ln $)$ Diameter $))+(0.7347) *($ Ln $($ Height $))$
\end{abstract}

Key words: Dyera polyphylla, volume, merchantable, Spiegel Relascope Bitterlich, model

\begin{abstract}
ABSTRAK
Pengembangan jenis Jelutung Rawa membutuhkan informasi yang lengkap terkait perkiraan hasil yang akan diperoleh. Perkiraan hasil dapat diperoleh dengan menduga volume tegakan menggunakan persamaan penduga volume pohon. Penelitian ini bertujuan mendapatkan model-model penduga volume terbaik jenis Jelutung Rawa untuk volume pohon total dan volume kayu yang dapat diperdagangkan. Penyusunan model penduga volume ini menggunakan 96 sampel pohon terpilih yang mewakili kondisi tegakan secara keseluruhan. Pohon sampel tersebut diukur dengan menggunakan Spiegel Relaskop Bitterlich (SRB) sehingga sampel pohon tidak ditebang. Modelmodel penduga pohon yang diujicobakan terdiri dari model linear dan non-linear dengan peubah tunggal (diameter) dan ganda (diameter dan tinggi pohon). Hasil penelitian ini menunjukkan penggunaan diameter sebagai peubah tunggal dapat digunakan menyusun model penduga volume pohon baik volume total maupun volume kayu yang dapat diperdagangkan. Namun demikian, penambahan variabel tinggi kedalam model tetap diperlukan. Model penduga volume pohon dengan dua variabel diameter dan tinggi digunakan untuk menyusun tabel volume standar. Koefisien determinasi naik $<2 \%$ dari model dengan peubah diameter. Model terbaik penduga volume baik satu atau dua peubah mempunyai $\mathrm{R}^{2}$ yang tinggi ( $\left.>80 \%\right)$. Model terbaik untuk menduga volume pohon total yakni 1) menggunakan peubah tunggal (diameter): Ln Volume $=-7,9444+(2,1952) *(\operatorname{Ln}($ Diameter $))$; dan 2$)$ menggunakan peubah ganda (diameter dan tinggi): volume $=2,4081 * 10^{-4} *\left(\right.$ Diameter $^{2}$. Tinggi) ${ }^{0,80871}$. Model terbaik untuk menduga volume pohon merchantable yakni 1) menggunakan peubah diameter: $\operatorname{Ln}$ Volume $=-8,2598+(2,2843)$ * $(\operatorname{Ln}($ Diameter $)) ; 2)$ menggunakan peubah diameter dan tinggi:Ln Volume $=-9,0589+(1,89958) *(\operatorname{Ln}($ Diameter $))$ $+(0,7347) *($ Ln(tinggi) $)$.
\end{abstract}

Kata kunci: Jelutung rawa, volume, Spiegel Relascope Bitterlich, model 


\section{PENDAHULUAN}

Pengambilan keputusan dalam pengelolaan hutan alam dan tanaman membutuhkan informasi yang terkait dengan kondisi tegakan masa lampau, sekarang, dan akan datang (Peng, 2000). Kondisi tersebut termasuk pertumbuhan dan perkembangan tegakan berupa pertumbuhan volume, kematian, dan perubahan kondisi tegakan. Perkembangan kondisi tegakan tersebut harus terus dimonitor dalam rentang waktu yang panjang. Hal ini karena hutan merupakan sistem biologi yang dinamis dan akan selalu berubah seiring perubahan waktu (Peng, 2000). Prosesproses tersebut harus mendapat perhatian dalam manajemen pengelolan hutan alam dan tanaman termasuk menentukan alternatif pengelolaan hutan, prediksi pertumbuhan dan pilihan sistem silvikultur (Vanclay, 1994).

Pengelolaan hutan harus memperhatikan karakteristik dari setiap tegakan. Karakteristik tegakan termasuk pertumbuhan dan hasil tegakan sangat berbeda-beda. Kondisi ini sangat terkait dengan jenis, umur dan variasi tempat tumbuh (Sturtevant and Seagle, 2004) dan tujuan dari penggunaan jenis tersebut (Tewari et al., 2002). Secara umum, hutan di daerah tropis mempunyai data numerik yang terbatas (Philips et al., (2003). Hal ini akan menjadi kendala dalam pengambilan keputusan untuk pengelolaan hutan jangka panjang. Keterbatasan ini menyebabkan banyak prediksi terkait dengan pertumbuhan dan hasil dilakukan dengan menggunakan data-data simulasi (Philips et al., 2003). Kondisi ini berbeda dengan negara-negara lain, beberapa diantara mereka mempunyai data menerus (time series) terkait dengan pertumbuhan dan hasil tegakan dalam jangka yang sangat panjang $>20$ tahun (Onyekwelu et al., 2006, Trasobares et al., 2004 ).

Keterbatasan data menerus berpengaruh terhadap manajemen pengelolaan hutan terutama prediksi pertumbuhan dan hasil menjadi sangat sulit dilakukan. Kondisi ini juga terjadi pada tegakan jenis Jelutung Rawa. Informasiinformasi mengenai pertumbuhan dan hasil tegakan jenis ini sangat terbatas termasuk prediksi volume pohonnya. Prediksi volume pohon dengan menggunakan model-model penduga volume terbaik melalui pendekatan metode kuadrat terkecil (OLS: Ordinary Least Square) (Brandies et al., 2006). Akurasi dan ketepatan dugaan dari model regresi dapat ditingkatkan dengan menggunakan model-model regresi (tabel volume) yang bersifat spesifik (Brandies et al., 2006).
Penelitian ini menggunakan model-model regresi baik model linear dan non linear. Penyusunan model regresi ini menggunakan diameter setinggi dada (dbh: 1,3 m) dan tinggi total serta kombinasi dari kedua dimensi pohon tersebut. Penyusunan model volume untuk menduga volume pohon total dan volume kayu perdagangan (volume pohon sampai dengan diameter $\geq 10 \mathrm{~cm}$ ) (Brandies et al., 2006). Tujuan penelitian ini yakni mendapatkan model-model penduga volume terbaik jenis jelutung rawa untuk volume pohon total dan kayu yang dapat diperdangkan. model-model tersebut digunakan untuk menyusun tabel volume jenis Jelutung Rawa.

\section{BAHAN DAN METODE}

\section{A. Lokasi Penelitian}

Tegakan jelutung rawa yang menjadi obyek penelitian berada di Provinsi Kalimantan Tengah (Gambar 1). Pemilihan lokasi ini didasarkan pertimbangan bahwa lokasi tersebut mempunyai tegakan dengan umur lebih dari 10 tahun dan dipelihara secara intensif. Karakteristik tempat tumbuhnya merupakan areal gambut dengan drainase yang cukup memadai. Drainase ini dibuat dengan tujuan agar tanaman muda tidak jenuh air sehingga tanaman mampu tumbuh dengan baik. Lebar saluran drainase ini yakni 5 meter. Pada saat penelitian dilakukan lokasi tampak kering dipermukaan tetapi pada kedalaman hampir 1 meter masih berair. Hal ini akan mempengaruhi pertumbuhan tanaman jelutung rawa tersebut. Jarak tanaman yang digunakan yakni $3 \mathrm{~m} \times 3 \mathrm{~m}$ (jarak antar tanaman).

\section{B. Bahan dan Alat}

Pengukuran diameter pohon menggunakan SRB (Spiegel Relascope Bitterlich) dan tinggi pohon menggunakan Haga meter. Penelitian ini menggunakan tegakan jelutung rawa umur 19 Tahun (tahun tanam 1992). Variasi kelas diameter sebagai pertimbangan utama dalam pengambilan sampel pohon. Pohon contoh yang digunakan untuk penyusun model penduga volume jenis jelutung rawa sebanyak 96 pohon contoh.

\section{Pengambilan Data Diameter Pohon dengan SRB}

Pengambilan data penelitian dilaksanakan pada bulan Juli dan Oktober 2011. Diameter pohon diukur menggunakan SRB (Spiegel 
Relascop Bitterlich). Pertimbangan penggunaan alat ini yakni pengambilan data diameter pohon per seksi tidak dapat dilakukan secara langsung sehingga pengukuran diameter tersebut menggunakan pengukuran secara tidak langsung. Hal ini karena tanaman jelutung rawa yang ada merupakan tegakan yang belum ditebang sehingga penebangan tidak mungkin untuk dilakukan. Data diameter pohon diambil pada ketinggian $20 \mathrm{~cm}$ (di atas tanah), 1,3 meter, 2 meter dan panjang setiap seksi 2 meter. Pengukuran tinggi pohon total dengan menggunakan haga meter.

\section{Karakteristik Pohon Contoh}

Pertimbangan utama dalam pemilihan pohon contoh yakni ketersebaran diameter tegakan yang diwakili oleh pohon contoh. Pertimbangan pemilihan pohon contoh yang lain yakni: pohon contoh harus sehat yang ditujukkan tidak ada gangguan dari penyakit atau gangguan pertumbuhan lain. Karakteristik pohon contoh ini menjadi dasar dalam penggunaan model-model terpilih untuk menduga volume pohon baik volume total maupun volume kayu perdagangan (Tabel 1). Pohon contoh yang diambil sebanyak 96 pohon contoh yang terbagi dalam delapan kelas diameter dan tinggi. Banyaknya pohon contoh memenuhi syarat minimal untuk penyusunan model penduga volume pohon (Loetsch and Zohrer, 1973). Pengelompokan ini dilakukan dengan tujuan untuk memudahkan pendiskripsian masing-masing pohon contoh. Pengelompokan ini didasarkan pembuatan kelompoka yang dikemukakan Walpole (1992). Banyaknya kelompok yang dibuat tergantung banyaknya jumlah pohon yang akan dikelompokkan (Walpole, 1995).

\section{E. Pengolahan Data}

\section{Diameter pohon}

Penggunaan SRB sebagai alat untuk mengukur diameter pohon dengan cara nondestruktive. Penggunaan SRB ini harus digunakan oleh personal yang terlatih karena alat ini merupakan alat yang bersifat optik. Contoh peng-gunaan SRB ini dapat dilihat pada Gambar 2.

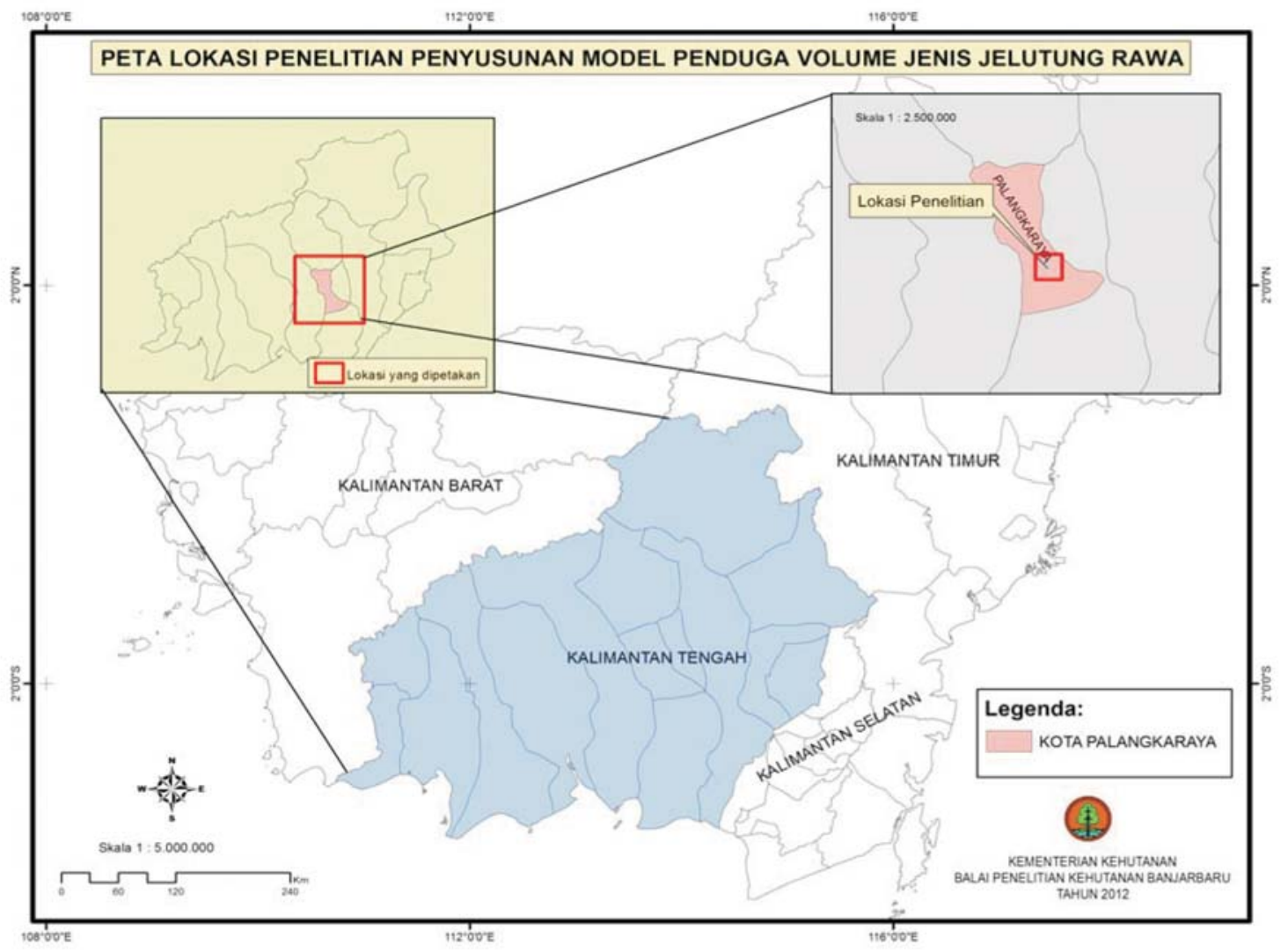

Gambar (Figure) 1. Lokasi penelitian (Study site) 
Tabel (Table) 1. Karakteristik pohon 96 sampel (Tree Characteristic of 96 sampel)

\begin{tabular}{|c|c|c|c|c|c|c|c|c|c|}
\hline \multirow{2}{*}{$\begin{array}{c}\text { Kelas } \\
\text { Diameter }\end{array}$} & \multicolumn{8}{|c|}{ Kelas Tinggi (Height Class) } & \multirow{2}{*}{$\begin{array}{c}\text { Jumlah } \\
\text { (Number) }\end{array}$} \\
\hline & $13,0-13,8$ & $13,8-14,6$ & $14,6-15,4$ & $15,4-16,3$ & $16,3-17,1$ & $17,1-17,9$ & $17,9-18,7$ & $18,7-19,5$ & \\
\hline $17,8-19,95$ & 5 & & & 1 & & & & & 6 \\
\hline $19,95-22,1$ & 4 & 6 & 4 & 8 & 1 & & & & 23 \\
\hline $22,1-24,25$ & 1 & 2 & 6 & 11 & 2 & 3 & 1 & & 26 \\
\hline $24,25-26,4$ & & & 3 & 5 & 4 & 5 & 2 & & 19 \\
\hline $26,4-28,55$ & & & & 3 & 5 & & 1 & 2 & 11 \\
\hline $28,55-30,7$ & & & & 1 & 2 & & 1 & 1 & 5 \\
\hline $30,7-32,85$ & & & & & 1 & 1 & 1 & 2 & 5 \\
\hline $32,85-35,0$ & & & & & & & 1 & & 1 \\
\hline Jumlah & 10 & 8 & 13 & 29 & 15 & 9 & 7 & 5 & 96 \\
\hline
\end{tabular}

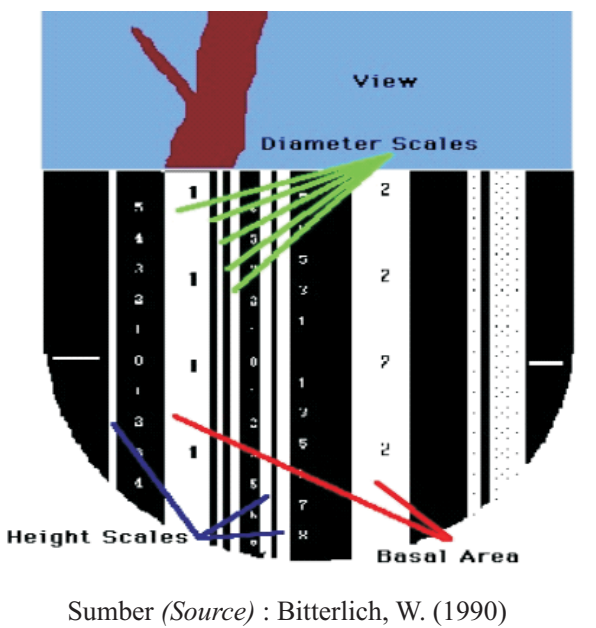

Gambar (Figure) 2. Contoh penggunaan SRB (SRB application)

Berdasarkan contoh hasil pengukuran tersebut, perhitungan diameter pohon dirumuskan sebagai berikut:

$\mathrm{d}(\mathrm{cm})=\mathrm{H} *(\mathrm{~L}+0,25 *(\mathrm{~S}+\mathrm{s})) * 2$

Keterangan (Remarks) : d (cm): diameter; $\mathrm{H}$ : jarak pengukuran; L: nilai 0 atau 1 ; S: nilai $0,1,2,3$, dan 4; s: nilai 0,2 (masuk di band kecil), 0,4 (masuk di setengah band), 0,6 (masuk lebih dari setengah band), 0,8 (hampir memenuhi band)

Pada contoh kasus Gambar 2. diameter pohon dapat ditentukan (jarak pengukuran 20 $\mathrm{m}): \mathrm{d}(\mathrm{cm})=20 *(1+0,25 *(3+0,2)) *=72 \mathrm{~cm}$. Jarak pengukuran ini harus dikoreksi untuk seksiseksi pohon yang lebih tinggi/rendah dari jarak datarnya karena jarak pengukuran akan bertambah besar (Gambar 3). Perhitungan jarak dirumuskan sebagai berikut:

$\overline{\mathrm{d}}=\sqrt{\mathrm{d}^{2}}=(\text { jarak datar })^{2}+(\overline{\mathrm{bc}})^{2}$ atau

$\overline{\mathrm{e}}=\sqrt{\mathrm{e}^{2}}=(\text { jarak datar })^{2}+(\overline{\mathrm{ab}})^{2}$

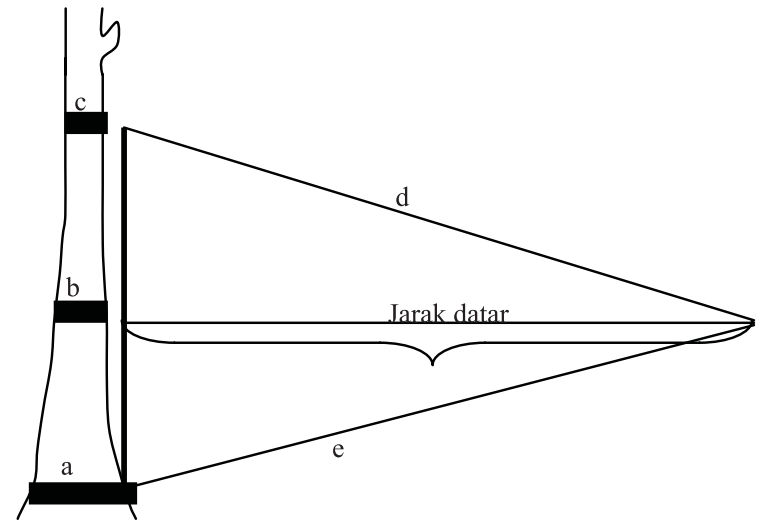

Gambar(Figure) 3. Ilustrasi perhitungan jarak pengukuran pada seksi-seksi yang lebih tinggi (Description of measurement distance calculated on each tree section)

\section{Volume pohon}

Volume total pohon ditentukan dari hasil pengukuran pohon contoh per sortimen batang. 
Sortimen batang ini dengan panjang 2 meter. Sortimen batang ditentukan dengan pengukuran diameter per seksi. Pengukuran diameter pohon per seksi menggunakan SRB. Perhitungan volume per seksi pohon ditentukan berdasarkaan rumus Smalian (Husch, 1963):

$\mathrm{Vs}=\frac{(\mathrm{Bu}+\mathrm{Bp})}{2} \times \mathrm{L}$ dan $\mathrm{V}_{\mathrm{p}}=\sum \mathrm{Vs}$

Keterangan (Remarks) : Vs: Volume per seksi $\left(\mathrm{m}^{3}\right)$; Bu: luas bidang dasar ujung sortimen $\left(\mathrm{m}^{2}\right)$; Bp: luas bidang dasar pangkal sortimen $\left(\mathrm{m}^{2}\right)$; L: panjang sortimen $(\mathrm{m})$; Vp: volume pohon contoh $\left(\mathrm{m}^{3}\right)$.

\section{F. Analisis Data}

\section{Penyusunan model penduga volume}

Model penduga volume pohon yang akan diujikan terdiri dari model linear dan non linear. Model-model regresi tersebut terdiri dari satu peubah bebas (diameter) atau turunannya dan dua peubah bebas (diameter dan tinggi) serta kombinasi dari kedua peubah bebas tersebut.

Model-model penduga tersebut yakni:

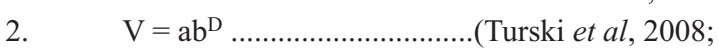

$$
\begin{aligned}
& \text { Brandies et al.,2006) } \\
& \text { 3. } \mathrm{V}=\mathrm{a}+\mathrm{bD}+\mathrm{cD}^{2} \text {..............(Turski et al.,2008) } \\
& \text { 4. } \quad \mathrm{V}=\mathrm{a} \mathrm{D}{ }^{\mathrm{b}} \mathrm{H}^{\mathrm{c}} \text {......................(Brown and Lugo, }
\end{aligned}
$$

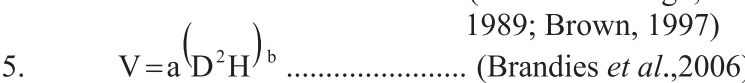

$$
\begin{aligned}
& \text { 6. } \quad \ln \mathrm{V}=\mathrm{a}+\mathrm{b} \ln (\mathrm{D}) \text {...................... (Brandies et al., 2006; } \\
& \text { Akinnifesi and Akinsami, 1995) }
\end{aligned}
$$

7. $\quad \ln \mathrm{V}=\mathrm{a}+\mathrm{b} \ln \left(\mathrm{D}^{2} \mathrm{H}\right)$.................(Brandies et al.,2006 Akinnifesi and Akinsami, 1995)

8. $\quad \ln \mathrm{V}=\mathrm{a}+\mathrm{b} \ln (\mathrm{D})+\mathrm{c} \ln (\mathrm{H})$........ (Akinnifesi and Akinsami, 1995)

Keterangan (Remarks) : V: volume $\left(\mathrm{m}^{3}\right)$; D: diameter setinggi dada $(\mathrm{cm}) ; \mathrm{H}$ : tinggi pohon (m); a,b,c: parameter persamaan; rumus dari Brandies et al. (2006) merupakan modifikasi darimodel alometrik biomassa.

\section{Pemilihan model terbaik}

Model terbaik ditentukan dengan kriteria pemilihan model terbaik yakni R2 maksimum, R2 terkoreksi maksimum, dan simpangan baku minimum (Drapper dan Smith, 1992). Modelmodel yang akan digunakan dalam penyusunan model penduga volume harus memenuhi kriteria keakuratan model yakni simpangan agregatif (SA<
$1 \%$ ) dan simpangan relatif (SR $<10 \%$ ) (Spurr, 1952). Kriteria tersebut dirumuskan sebagai berikut: $\mathrm{SA}(\%)=\frac{\sum \mathrm{Va}-\sum \mathrm{Vt}}{\sum \mathrm{Vt}} \times 100 \%$ dan

$\mathrm{SR}(\%)=\frac{\sum|\mathrm{Va}-\mathrm{Vt}|}{\mathrm{N}} \times 100 \%$

Keterangan (Remarks) : SR: simpangan relatif (\%); SA: simpangan agregatif (\%); Vt: Volume dugaan pohon $\left(\mathrm{m}^{3}\right)$ : berdasar persamaan); Va: Volume aktual pohon sampel $\left(\mathrm{m}^{3}\right) ; \mathrm{N}$ : jumlah pohon model.

\section{Bias, akurasi, dan ketepatan model penduga}

Kriteria ini digunakan untuk mendapatkan besarnya kesalahan sistematis (bias; e); gambaran kedekatan nilai-nilai pengukuran terhadap nilai rata-ratanya yang ditunjukkan oleh ketelitian pendugaan (s); dan ketepatan pendugaan (kombinasi antara bias dan ketelitian pendugaan) yang ditunjukkan oleh nilai Root Means Square Errors (van Laar and Akca, 1997). Besarnya bias, akurasi, dan ketelitian pendugaan ditunjukkan dengan

$$
\begin{aligned}
& \mathrm{e}=\left(\frac{\sum_{\mathrm{i}=1}^{\mathrm{rum}} \frac{(\mathrm{Vt}-\mathrm{Va})}{\mathrm{Va}}}{\mathrm{n}}\right) \times 100 \% \text {; }
\end{aligned}
$$

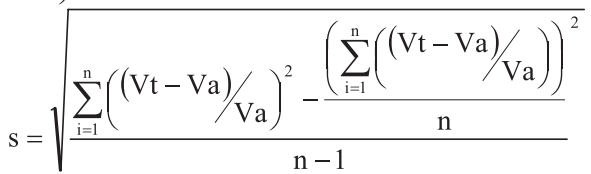

$$
\begin{aligned}
& \mathrm{RMSE}=\sqrt{\sum_{\mathrm{i}=1}^{\mathrm{n}} \frac{((\mathrm{Vt}-\mathrm{Va}) / \mathrm{Va})^{2}}{\mathrm{n}}} \times \begin{array}{r}
100 \% \ldots \ldots \ldots \ldots . . . . . . \\
(\text { van Laar and Akca, 1997) }
\end{array}
\end{aligned}
$$

Keterangan (Remarks) : e: rata-rata bias (\%); s: simpangan baku $\left(\mathrm{m}^{3}\right)$; RMSE: Root mean square eror; $\mathrm{Vt}$ : volume berdasarkan persamaan $\left(\mathrm{m}^{3}\right)$; Va: volume hasil pengukuran $\left(\mathrm{m}^{3}\right)$; $\mathrm{n}$ : jumlah pohon contoh.

\section{HASIL DAN PEMBAHASAN}

\section{A. Hubungan Diameter dan Tinggi}

Analisis korelasi digunakan untuk menilai keeratan hubungan antara diameter dengan tinggi. Hasil analisis korelasi menunjukkan $\mathrm{r}=0,73$ (Gambar 2). Nilai $r$ tersebut menunjukkan keeratan hubungan linear yang tinggi antara diameter dengan tinggi $(r>0,5)$. Selain itu, nilai $r$ ini menunjukkan $73 \%$ keragaman tinggi disebabkan oleh adanya kera- 
gaman diameter pohon.

Berdasarkan hasil analisis korelasi ini, persyaratan menyusun persamaan (model) volume pohon dengan menggunakan satu peubah (diameter atau tinggi) atau dua peubah (diameter dan tinggi) terpenuhi (Siswanto dan Imannudin, 2008; Siswanto dan Herbagung, 2004; Krisnawati dan Bustomi, 2004).

\section{B. Model Penduga Volume Pohon Total}

Volume pohon total didefinisikan sebagai volume pohon sampai dengan ukuran diameter terkecil yang masih memungkinkan diukur dengan menggunakan Spiegel Relaskop Bitterlich (SRB). Diameter terkecil yang digunakan dalam penyusunan model penduga volume total yakni $3 \mathrm{~cm}$.

\section{Model penduga volume pohon total dengan menggunakan peubah diameter}

Penyusunan model penduga volume menggunakan model linear dan non linear. Hasil analisis regresi menunjukkan model-model penduga volume memiliki koefisien determinasi yang tinggi $\left(\mathrm{R}^{2}>75 \%\right)$. Secara umum, model penduga yang digunakan memenuhi kriteria akurasi model yang ditujukkan Simpangan Agregatif $(\mathrm{SA}<1 \%$ ) dan Simpangan Relatif (SR $<10 \%$ ) (Tabel 2). Berdasarkan kriteria ini, semua model dapat digunakan untuk menduga volume pohon total. Jika dilihat dari koefisien determinasi $\left(\mathrm{R}^{2}\right)$-nya, model penduga volume ini mempunyai nilai $\mathrm{R}^{2}$ tidak jauh berbeda. Berdasarkan kriteria pemilihan model terbaik (simpangan baku terkecil; $\mathrm{R}^{2}$ adj terbesar; $\mathrm{SR}$ dan SA terkecil), model terbaik yang dipilih yakni model 3. Model ini mempunyai koefisien determinasi relatif besar dan simpangan dugaan yang kecil (s, SR, dan SA). Gambaran jauh dekatnya simpangan dugaan terhadap garis persamaan regresi menunjukkan pola hubungan yang serupa antar model penduga yang

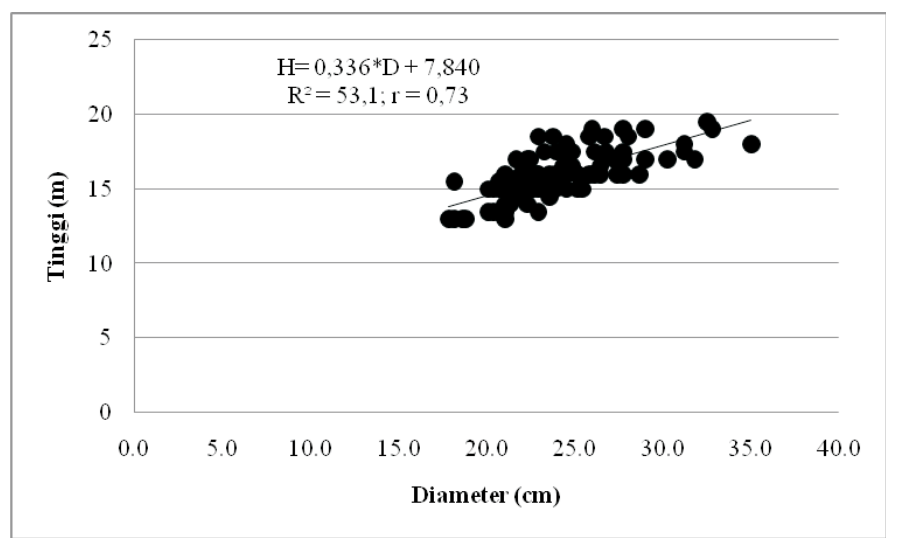

Gambar (Figure) 2. Hubungan diameter dan tinggi (Relationship of height and diameter)

Tabel(Table) 2. Model penduga volume pohon total dengan menggunakan peubah diameter (Estimating model of total volume with diameter as independent variable)

\begin{tabular}{|l|l|c|c|c|c|c|}
\hline No & \multicolumn{1}{|c|}{ Model } & $\begin{array}{c}\mathrm{R}^{2} \\
(\%)\end{array}$ & $\begin{array}{c}\mathrm{R}^{2} \mathrm{adj} \\
(\%)\end{array}$ & $\begin{array}{c}\mathrm{S} \\
\left(\mathrm{m}^{3}\right)\end{array}$ & $\begin{array}{c}\mathrm{SA} \\
(\%)\end{array}$ & $\begin{array}{c}\mathrm{SR} \\
(\%)\end{array}$ \\
\hline 1. & $\mathrm{~V}=6,80007 * 10^{-4}(\mathrm{D})^{1,996}$ & 80,0 & 79,6 & 0,0606 & $-0,16$ & 5,03 \\
2. & $\mathrm{V}=\left(6,433 * 10^{-2}\right) *(1,0771)^{\mathrm{D}}$ & 77,4 & 76,9 & 0,0645 & $-0,35$ & 5,36 \\
3. & $\mathrm{~V}=-0,612+0.0482 * \mathrm{D}-0.000256^{*} \mathrm{D}^{2}$ & 81,4 & 81,0 & 0,0585 & $-0,23$ & 4,84 \\
4. & $\mathrm{LnV}=-7,9444+(2,1952) *(\operatorname{Ln}(\mathrm{D}))$ & 81,8 & 81,6 & 0,0619 & 0,78 & 4,94 \\
\hline
\end{tabular}

Keterangan (Remarks): V: volume pohon total (tree volum: $\left.\mathrm{m}^{3}\right) ; \mathrm{D}:$ Diameter $(\mathrm{cm}) ; \mathrm{H}$; tinggi pohon (height: $\left.\mathrm{m}\right) ; \mathrm{R}^{2}$ : koefisien determinasi (coefficient of determination: \%) ; $\mathrm{R}^{2}$ adj: koefisien determinasi terkoreksi coefficient of adjusted determination:\%)s: simpangan baku (standard deviation: $\mathrm{m}^{3}$ ); SR: simpangan Relatif (relative deviation: \%); SA: simpangan agregatif (agregatif deviation: \%) 
Model 3 tidak dapat digunakan untuk menduga volume pohon dengan diameter $<14$ $\mathrm{cm}$. Penggunan model 3 untuk menduga volume pohon menghasilkan dugaan volume pohon yang negatif (Gambar 4) sehingga model 3 tidak logis digunakan untuk menduga volume pohon. Pertimbangan kelogisan ini menjadi dasar untuk memilih model terbaik pada tahap selanjutnya. Pada tahap pemilihan model akhir, model 3 tidak dapat digunakan untuk menduga volume pohon jenis jelutung rawa secara keseluruhan. Berdasarkan pertimbangan tersebut pemilihan model penduga akhir tidak mengikutkan model 3 sebagai pilihan untuk penyusun model penduga volume pohon.

Model-model tersebut harus memenuhi kriteria bias dugaan yang kecil, ketelitian yang tinggi, dan akurasi dugaan yang tepat (van Laar and Akca, 1997). Berdasarkan kriteria ini, modelmodel yang telah disusun cukup baik menduga volume pohon total (Tabel 3). Model 4 mempunyai bias dugaan yang kecil dan akurasi dugaan yang tepat (nilai RMSE yang kecil).

Pada tahap akhir pemilihan model terbaik dilakukan dengan menggabungkan kriteria pemilihan model terbaik (Drapper and Smith, 1992) dan kriteria oleh Akca dan Laar (1997). Berdasarkan kriteria-kriteria gabungan tersebut, pemilihan model terbaik dilakukan dengan sistem skoring. Hal ini karena model-model penduga volume pohon total tidak selalu konsisten sebagai model terbaik untuk kesluruhan kriteria (Tabel 2 dan 3). Hasil skoring menunjukkan model (4): Ln V = $-7,9444+(2,1952) *(\operatorname{Ln}(\mathrm{D}))$ sebagai model terbaik penduga volume pohon total menggunakan peubah diameter.

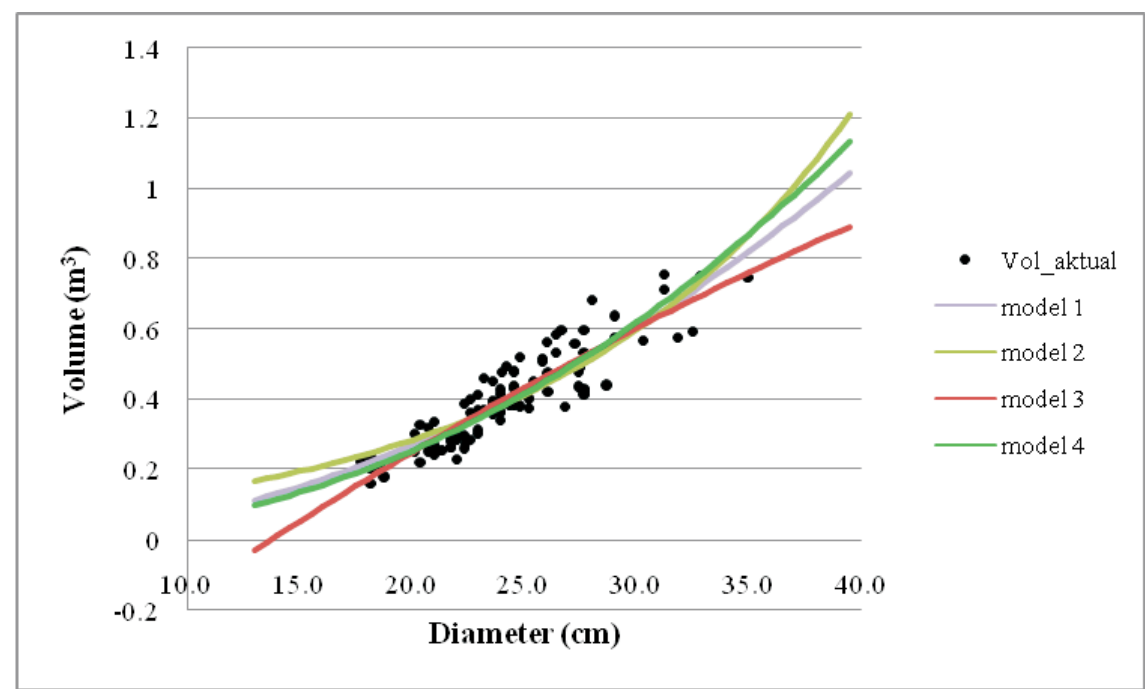

Gambar(Figure) 4. Gambaran antara volume aktual terhadap garis persamaan regresi beberapa model penduga volume total (Description of actual volume towards regression equation lines some of tree volume model)

Tabel (Table) 3. Bias, simpangan baku, dan Root Mean Square Errors untuk model penduga volume total menggunakan peubah bebas diameter (Bias, standard deviation, and Root Mean Square Errors for estimatiom model of total volume with diameter as single variable)

\begin{tabular}{|l|l|c|c|c|c|}
\hline No & \multicolumn{1}{|c|}{ Model } & $\begin{array}{l}\text { Bias } \\
(\mathrm{e})\end{array}$ & $\begin{array}{l}\text { Simpangan } \\
\text { Baku }(\mathrm{s})\end{array}$ & $\begin{array}{l}\text { RMSE } \\
(\%)\end{array}$ & $\begin{array}{l}\text { Total } \\
\text { skor }\end{array}$ \\
\hline 1. & $\mathrm{~V}=6,80007 * 10^{-4}(\mathrm{D})^{1,996}$ & 2,960 & 0,0606 & $-0,148$ & 11 \\
2. & $\mathrm{~V}=\left(6,433 * 10^{-2}\right) *(1,0771)$ & 3,878 & 0,0645 & 0,014 & 15 \\
4. & $\mathrm{Ln} \mathrm{V}=-7,9444+(2,1952) *(\operatorname{Ln}(\mathrm{D}))$ & 1,102 & 0,0619 & 0,082 & 10 \\
\hline
\end{tabular}

Keterangan (Remarks) : V: volume pohon total (tree volum: $\left.\mathrm{m}^{3}\right)$; D: diameter $(\mathrm{cm}) ; \mathrm{H}$; tinggi pohon (height: $\left.\mathrm{m}\right)$; e: bias (bias : \%); s: simpangan baku (standard deviation: \%); RMSE: Root Mean Square Errors (\%) 


\section{Model penduga volume pohon total dengan} menggunakan peubah diameter dan tinggi

Penggunaan variabel tinggi dalam penyusunan model penduga volume pohon ini dapat meningkatkan besarnya R2 (koefisien determinasi) dibandingkan dengan model penduga volume pohon menggunakan peubah diameter (Tabel 4). Secara umum, model-model penduga volume pohon menggunakan peubah bebas diameter dan tinggi mempunyai R2 $>80 \%$. Namun demikian, penambahan tinggi sebagai peubah bebas tidak meningkatkan secara nyata terhadap besarnya R2. Brandies et al. (2006) menyatakan penggunaan tinggi untuk menduga volume pohon memiliki keterbatasan dalam pengukurannya sehingga diameter sebagai peubah tunggal dapat digunakan untuk menduga volume pohon. Penambahan tinggi sebagai peubah bebas menaikkan rata-rata $1 \%$ koefisien determinasi dibandingkan model menggunakan peubah tunggal diameter.

Model-model penduga volume pohon menggunakan diameter dan tinggi memenuhi kriteria keakuratan model (Tabel 4). Modelmodel yang dihasilkan mempunyai $\mathrm{SR}<1 \%$ dan $\mathrm{SA}<10 \%$ (Spurr, 1952). Berdasarkan kriteria ini, semua model penduga volume dapat digunakan untuk menduga volume total.

Pemilihan model terbaik dilakukan dengan beberapa kriteria yakni koefisien determinasi terkoreksi ( $\mathrm{R}^{2}$ adj) maksimum, simpangan dugaan (s) minimum (Drapper and Smith, 1992), bias, dan Root Mean Square Errors (van Laar and Akca, 1997). Keseluruhan model penduga volume cenderung memiliki bias dugaan yang kecil dengan akurasi dugaan yang tinggi (Tabel 5). Berdasarkan kriteria tersebut, model penduga volume yang telah disusun tidak konsisten sebagai model terbaik untuk keseluruhan kriteria yang digunakan sehingga pemilihan model terbaik dilakukan dengan menggunakan pembobotan untuk setiap kriteria.

Berdasarkan hasil pembobotan secara total, model (2) adalah model terbaik. Model 2 mempunyai koefisien determinasi yang tinggi dengan sisaan pendugaan (SA dan SR) yang kecil dibandingkan dengan model-model yang lain (kecuali simpangan baku). Model terbaik dengan penambahan variabel tinggi hanya meningkatkan koefisien determinasi sebesar $1,6 \%$ terhadap model penduga volume menggunakan peubah tunggal diameter pohon. Model (2) V $=2,4081$ *

Tabel(Table) 4. Model penduga volume pohon total dengan menggunakan peubah diameter dan tinggi (estimating model of total volume with diameter and height as independent variable)

\begin{tabular}{|l|c|c|c|c|c|c|}
\hline No & \multicolumn{1}{|c|}{ Model } & $\begin{array}{c}\mathrm{R}^{2} \\
(\%)\end{array}$ & $\begin{array}{c}\mathrm{R}^{2} \text { adj } \\
(\%)\end{array}$ & $\begin{array}{c}\mathrm{s} \\
\left(\mathrm{m}^{3}\right)\end{array}$ & $\begin{array}{c}\text { SA } \\
(\%)\end{array}$ & $\begin{array}{c}\mathrm{SR} \\
(\%)\end{array}$ \\
\hline 1. & $\mathrm{~V}=0,0002747 *(\mathrm{D})^{1,6804}(\mathrm{H})^{0,689025}$ & 81,7 & 81,2 & 0,0579 & $-0,17$ & 4,65 \\
2. & $\mathrm{V}=2,4081 * 10^{-4} *\left(\mathrm{D}^{2} \mathrm{H}\right)^{0,80871}$ & 82,7 & 82,3 & 0,0580 & $-0,15$ & 4,64 \\
3. & $\mathrm{Ln} \mathrm{V}=-8,826+(0,86123) *\left(\operatorname{Ln}\left(\mathrm{D}^{2} \mathrm{H}\right)\right)$ & 83,2 & 83,0 & 0,0585 & 0,83 & 4,64 \\
4. & $\mathrm{Ln} \mathrm{V}=-8,6552+(1,8496) *(\operatorname{Ln}(\mathrm{D}))+(0,6535) *(\operatorname{Ln}(\mathrm{H}))$ & 83,4 & 83,0 & 0,0586 & 0,82 & 4,66 \\
\hline
\end{tabular}

Keterangan (Remarks) : V: volume pohon total ( tree volum: $\left.\mathrm{m}^{3}\right)$; D: diameter $(\mathrm{cm}) ; \mathrm{H}$; tinggi pohon (height: $\left.\mathrm{m}\right) ; \mathrm{R}^{2}$ : koefisien determinasi (coefficient of determination: \%) ; $\mathrm{R}^{2}$ adj: koefisien determinasi terkoreksi coefficient of adjusted determination:\%)s: simpangan baku (standard deviation: $\mathrm{m}^{3}$ ); SR: simpangan relatif (relative deviation: \%); SA: simpangan agregatif (agregatif deviation: \%)

Tabel (Table) 5. Bias, simpangan baku, dan Root Mean Square Errors untuk model penduga volume total menggunakan peubah bebas diameter dan tinggi (Bias, standard deviation, and Root Mean Square Errors for estimatiom model of total volume with diameter and height as independent variable)

\begin{tabular}{|l|c|c|c|c|}
\hline No & \multicolumn{1}{|c|}{ Model } & Bias (e) & $\mathrm{S}(\%)$ & RMSE \\
\hline 1. & $\mathrm{~V}=0,0002747 *(\mathrm{D})^{1,6804}(\mathrm{H})^{0,689025}$ & 2,622 & 5,79 & $-0,081$ \\
2. & $\mathrm{~V}=2,4081 * 10^{-4} *\left(\mathrm{D}^{2} \mathrm{H}\right)^{0,80871}$ & 2,572 & 5,80 & $-0,054$ \\
3. & $\mathrm{Ln} \mathrm{V}=-8,826+(0,86123) *\left(\operatorname{Ln}\left(\mathrm{D}^{2} \mathrm{H}\right)\right)$ & 0,977 & 5,85 & $-0,066$ \\
4. & $\mathrm{Ln} \mathrm{V}=-8,6552+(1,8496) *(\operatorname{Ln}(\mathrm{D}))+(0,6535) *(\operatorname{Ln}(\mathrm{H}))$ & 0,950 & 5,86 & $-0,021$ \\
\hline
\end{tabular}

Keterangan (Remarks): V: volume pohon total (tree volum: $\left.\mathrm{m}^{3}\right)$; D: Diameter $(\mathrm{cm}) ; \mathrm{H}$; tinggi pohon (height: $\left.\mathrm{m}\right)$; e: bias (bias : \%); s: simpangan baku (standard deviation: \%); RMSE: Root Mean Square Errors (\%) 
$10^{-4 *}(\mathrm{D} 2 \mathrm{H})^{0,80871}$ digunakan untuk me-nyusun Tabel Volume Standar Jenis Jelutung Rawa.

\section{Model penduga volume kayu yang diper- dagangkan (merchantable volume)}

Volume kayu yang diperdagangkan (merchantable volume) yakni volume kayu pada diameter tertentu yang kemungkinan masih dapat diperdagangkan atau diolah untuk kebutuhan industri kayu. Menurut Brandies et al., (2006), volume kayu tersebut ditentukan sampai dengan diameter $\geq 10 \mathrm{~cm}$.

\section{Model penduga volume merchantable de- ngan menggunakan peubah diameter}

Penyusunan model penduga volume ini menggunakan diameter sebagai peubah bebasnya. Penggunaan peubah diameter dapat menduga volume merchantable. Keragaman volume dapat diterangkan oleh keragaman diameter lebih dari $50 \%$. Hal ini ditunjukkan oleh besarnya nilai R2 $>50 \%$ (Tabel 6). Berdasarkan Tabel 6, model (3) adalah model terbaik. Hal ini karena model (3) mempunyai sisaan dugaan yang paling kecil dibandingkan dengan ketiga model penduga volume yang lain. Model ini juga memiliki koefisien determinasi yang tinggi. Keseluruhan model penduga volume pohon yang telah disusun memenuhi kriteria keakuratan yakni SA $<1 \%$ dan SR $<10 \%$ (Spurr, 1952). Berdasarkan kriteria tersebut semua model penduga dapat digunakan untuk menduga volume merchantable.

Pertimbangan lain yang digunakan untuk mendapatkan model terbaik adalah kelogisan model. Kelogisan model terkait dengan penggunaan model tersebut dalam menduga volume pohon dengan diameter tertentu. Kelogisan ini dapat dilihat dari gambaran garis regresinya dalam menduga volume pohon (Gambar 5).
Berdasarkan Gambar 4. model 3 tidak dapat digunakan untuk menduga volume pohon dengan diameter yang kecil $<15 \mathrm{~cm}$ sehingga model 3 tidak dipilih sebagai model terbaik. Pada tahap pemilihan model terbaik selanjutnya menggunakan kriteria yang dikemukakan oleh van Laar dan Akca (1997). Kriteria-kriteria tersebut seperti pada Tabel 7.

Model penduga volume terbaik dipilih apabila model tersebut terbaik untuk keseluruhan kriteria. Berdasarkan Tabel 6 dan 7, model-model yang disusun tidak selalu terbaik untuk masingmasing kriteria sehingga pemilihan model menggunakan pembobotan pada masing-masing kriteria yang digunakan. Hasil pembobotan menunjukkan model (4) adalah model terbaik. model ini mempunyai koefisien determinasi yang besar dengan sisaan dugaan yang relatif kecil. Model (4) Ln Volume $=-8,2598+(2,2843) *$ $\mathrm{Ln}$ (Diameter)) digunakan untuk menyusun tabel volume merchantable jenis Jelutung Rawa.

\section{Model penduga volume merchantable de- ngan menggunakan peubah diameter dan tinggi \\ Variabel tinggi ditambahkan dalam} penyusunan model untuk menaikkan ketepatan dan akurasi dugaan volume pohon. Model penduga volume yang dihasilkan mempunyai $\mathrm{R}^{2}$ lebih dari $80 \%$ (Tabel 8). Nilai $\mathrm{R}^{2}$ ini tidak signifikan kenaikkannya dibandingkan menggunakan peubah tunggal diameter. Namun demikian, penyusunan tabel volume standar mensyaratkan penambahan tinggi dalam model penduga volume. Hal ini karena tinggi pohon menunjukkan kualitas tempat tumbuh tanaman (Wang \& Payandeh, 1995; Onyekwelu, 2005) sehingga penyusunan kualitas tempat tumbuh menggunakan tinggi.

Tabel(Table)6. Model penduga volume merchantable dengan menggunakan peubah diameter (estimating model of merchantable volume with diameter as independent variable)

\begin{tabular}{|c|l|c|c|c|c|c|}
\hline No & \multicolumn{1}{|c|}{ Model } & $\begin{array}{c}\mathrm{R}^{2} \\
(\%)\end{array}$ & $\begin{array}{c}\mathrm{R}^{2} \text { adj } \\
(\%)\end{array}$ & $\begin{array}{c}\mathrm{s} \\
\left(\mathrm{m}^{3}\right)\end{array}$ & $\begin{array}{c}\text { SA } \\
(\%)\end{array}$ & $\begin{array}{c}\text { SR } \\
(\%)\end{array}$ \\
\hline 1. & $\mathrm{~V}=5,14438 * 10^{-4}(\mathrm{D})^{2,07452}$ & 79,5 & 79,1 & 0,0625 & $-0,23$ & 5,12 \\
2. & $\mathrm{~V}=\left(5,8418 * 10^{-2}\right) *(1,08001)^{\mathrm{D}}$ & 76,9 & 76,4 & 0,0664 & $-0,21$ & 5,45 \\
3. & $\mathrm{~V}=-0,5832+0,0445 * \mathrm{D}-0,0001729 * \mathrm{D}^{2}$ & 80,8 & 80,4 & 0,0605 & $-0,14$ & 4,97 \\
4. & $\mathrm{Ln} \mathrm{V}=-8,2598+(2,2843) *(\operatorname{Ln}(\mathrm{D}))$ & 81,3 & 81,1 & 0,0638 & 0,86 & 5,05 \\
\hline
\end{tabular}

Keterangan (Remarks) : V: volume pohon total ( tree volume: $\left.\mathrm{m}^{3}\right)$; D: diameter $(\mathrm{cm}) ; \mathrm{H}$; tinggi pohon (height: $\left.\mathrm{m}\right) ; \mathrm{R}^{2}$ : koefisien determinasi (coefficient of determination: \%) ; $\mathrm{R}^{2}$ adj: koefisien determinasi terkoreksi coefficient of adjusted determination:\%) s: simpangan baku (standard deviation: $\mathrm{m}^{3}$ ); SR: simpangan relatif (relative deviation: \%); SA: simpangan agregatif(Agregatif deviation: \%) 
Model penduga volume yang disusun memenuhi kriteria keakuratan model: $\mathrm{SA}<1 \%$ dan SR $<10 \%$ (Spurr, 1952) sehingga modelmodel tersebut dapat digunakan menduga volume pohon. Model yang akan digunakan menyusun tabel volume standar adalah model terbaik untuk seluruh kriteria. Kriteria-kriteria yang digunakan seperti pada Tabel 8 dan kriteria bias, simpangan baku, dan RMSE yang kecil yang ditunjukkan oleh Tabel 9 (van Laar and Akca, 1997). Model penduga volume pohon tidak selalu terbaik untuk masing-masing kriteria

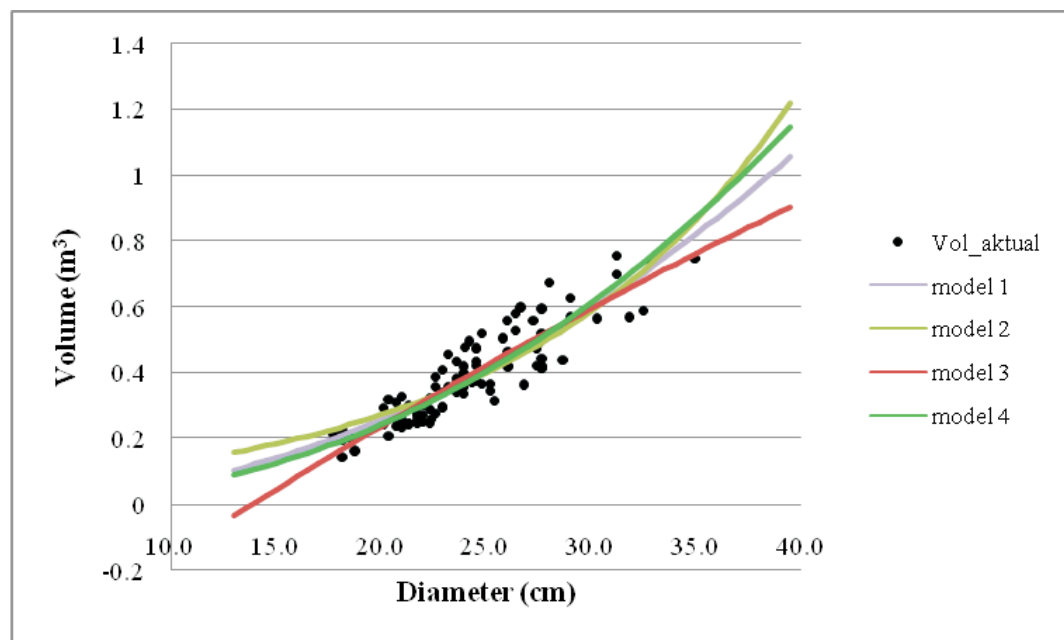

Gambar(Figure) 5. Gambaran antara volume aktual terhadap garis persamaan regresi beberapa model penduga volume merchantable (Description of actual volume towards regression equation lines some of merchantable volume model)

Tabel (Table) 7. Bias, simpangan baku, dan Root Mean Square Errors untuk model penduga volume total menggunakan peubah bebas diameter (Bias, standard deviation, and Root Mean Square Errors for estimatiom model of merchantable volume with diameter as single variable)

\begin{tabular}{|c|c|c|c|c|c|}
\hline No & Model & $\begin{array}{l}\text { Bias } \\
(\mathrm{e})\end{array}$ & $\begin{array}{l}\mathrm{S} \\
(\%)\end{array}$ & $\begin{array}{l}\text { RMSE } \\
(\%)\end{array}$ & $\begin{array}{c}\text { Total } \\
\text { Skor }\end{array}$ \\
\hline 1. & $\mathrm{~V}=5,14438 * 10^{-4}(\mathrm{D})^{2,07452}$ & 3,36 & 6,25 & $-0,179$ & 12 \\
2. & $\mathrm{~V}=\left(5,8418 * 10^{-2}\right) *(1,08001)^{\mathrm{D}}$ & 4,14 & 6,64 & 0,009 & 14 \\
4. & $\mathrm{Ln} \mathrm{V}=-8,2598+(2,2843)^{*}(\operatorname{Ln}(\mathrm{D}))$ & 1,26 & 6,38 & 0,085 & 10 \\
\hline
\end{tabular}

Keterangan (Remarks) : V: volume pohon total (tree volum: $\left.\mathrm{m}^{3}\right)$; D: diameter (cm); e: bias (bias: \%); s: simpangan baku (standard deviation: \%); RMSE: Root Mean Square Errors (\%)

Tabel (Table) 8. Model penduga volume merchantable dengan menggunakan peubah diameter dan tinggi (Estimating model of merchantable volume with diameter and height as independent variable)

\begin{tabular}{|l|l|l|l|l|r|c|}
\hline No & \multicolumn{1}{|c|}{ Model } & $\begin{array}{c}\mathrm{R}^{2} \\
(\%)\end{array}$ & $\begin{array}{l}\mathrm{R}^{2} \text { adj } \\
(\%)\end{array}$ & $\begin{array}{c}\mathrm{s} \\
\left(\mathrm{m}^{3}\right)\end{array}$ & $\begin{array}{c}\text { SR } \\
(\%)\end{array}$ & $\begin{array}{l}\mathrm{SA} \\
(\%)\end{array}$ \\
\hline 1. & $\mathrm{~V}=0,0001851 *(\mathrm{D})^{1,7231}(\mathrm{H})^{0,77045}$ & 81,6 & 80,1 & 0,0593 & 0,13 & 4,75 \\
2. & $\mathrm{~V}=1,7074 * 10^{-4} *\left(\mathrm{D}^{2} \mathrm{H}\right)^{0,84306}$ & 81,5 & 81,1 & 0,0593 & $-0,17$ & 4,76 \\
3. & $\mathrm{Ln} \mathrm{V}=-9,1932+(0,89796) *\left(\operatorname{Ln}\left(\mathrm{D}^{2} \mathrm{H}\right)\right)$ & 83,0 & 82,8 & 0,0598 & 0,93 & 4,76 \\
4. & $\mathrm{Ln} \mathrm{V}=-9,0589+(1,8958) *(\operatorname{Ln}(\mathrm{D}))+(0,7347) *(\operatorname{Ln}(\mathrm{H}))$ & 83,1 & 82,7 & 0,0600 & 0,92 & 4,76 \\
\hline
\end{tabular}

Keterangan (Remarks) : V: volume pohon total (tree volum: $\left.\mathrm{m}^{3}\right)$; D: diameter $(\mathrm{cm}) ; \mathrm{H}$; tinggi pohon (height: $\left.\mathrm{m}\right) ; \mathrm{R}^{2}$ : koefisien determinasi (coefficient of determination: \%); $\mathrm{R}^{2}$ adj: koefisien determinasi terkoreksi coefficient of adjusted determination:\%); s: simpangan baku (standard deviation: $\mathrm{m}^{3}$ ); SR: simpangan relatif (Relative deviation: \%); SA: simpangan agregatif (agregatif deviation: \%) 
Tabel (Table) 9. Bias, simpangan baku, dan Root Mean Square Errors untuk model penduga volume total menggunakan peubah bebas diameter dan tinggi (Bias, standard deviation, and Root Mean Square Errors for estimatiom model of merchantable volume with diameter and height as independent variable)

\begin{tabular}{|l|l|c|c|c|c|}
\hline No & \multicolumn{1}{|c|}{ Model } & $\begin{array}{c}\text { Bias } \\
(\mathrm{e})\end{array}$ & $\begin{array}{c}\mathrm{S} \\
(\%)\end{array}$ & $\begin{array}{c}\text { RMSE } \\
(\%)\end{array}$ & $\begin{array}{l}\text { Total } \\
\text { Skor }\end{array}$ \\
\hline 1. & $\mathrm{~V}=0,0001851 *(\mathrm{D})^{1,7231}(\mathrm{H})^{0,77045}$ & 2,55 & 5,93 & $-0,097$ & 14,5 \\
2. & $\mathrm{~V}=1,7074 * 10^{-4} *\left(\mathrm{D}^{2} \mathrm{H}\right)^{0,84306}$ & 2,83 & 5,93 & $-0,050$ & 15,5 \\
3. & $\mathrm{LnV}=-9,1932+(0,89796) *\left(\operatorname{Ln}\left(\mathrm{D}^{2} \mathrm{H}\right)\right)$ & 1,06 & 5,98 & $-0,069$ & 16 \\
4. & $\mathrm{Ln} \mathrm{V}=-9,0589+(1,8958) *(\operatorname{Ln}(\mathrm{D}))+(0,7347) *(\operatorname{Ln}(\mathrm{H}))$ & 1,04 & 6,00 & $-0,031$ & 14 \\
\hline
\end{tabular}

Keterangan (Remarks): V: volume pohon total (tree volum: $\left.\mathrm{m}^{3}\right)$; D: diameter (cm); H; tinggi pohon (height: $\left.\mathrm{m}\right)$; e: bias (bias: \%); s: simpangan baku (standard deviation: \%); RMSE: Root Mean Square Errors (\%)

Tabel (Table) 10. Model-model penduga volume pada beberapa jenis tanaman (Prediction model of tree volume on various species)

\begin{tabular}{|l|l|l|c|l|l|l|}
\hline No & \multicolumn{1}{|c|}{ Jenis } & \multicolumn{1}{|c|}{ Model Penduga Volume } & $\mathrm{r}$ & $\begin{array}{l}\mathrm{R}^{2} \\
(\%)\end{array}$ & $\begin{array}{l}\mathrm{SA} \\
(\%)\end{array}$ & $\begin{array}{l}\mathrm{SR} \\
(\%)\end{array}$ \\
\hline 1. & Acacia mangium & $V=0,0134^{*} 1,0643^{D} * 1,086^{H}$ & 0,86 & 74,6 & 2,35 & 0,03 \\
2. & Swietenia mahagoni & $\log V=-5,428^{*} 2,6914 \log D+0,9243 \log H$ & 0,92 & 83,8 & 6,87 & 0,11 \\
3 & Swietenia mahagoni & $V=0,0062^{*} 1,1483^{D}$ & 0,90 & 80,2 & 5,71 & 0,11 \\
4. & Gmelina arborea & $V=0,0138^{*}, 0713^{D} * 1,0876^{H}$ & 0,92 & 83,9 & 8,58 & 0,17 \\
5. & Gmelina arborea & $V=0,0168^{*} 1,1058^{D}$ & 0,90 & 81,5 & 10,62 & 0,21 \\
\hline
\end{tabular}

Sumber(Source): Susanty et al., (2006)

Keterangan (Remarks): V: volume pohon total (tree volum: $\left.\mathrm{m}^{3}\right)$; D: diameter $(\mathrm{cm}) ; \mathrm{H}$; tinggi pohon (height: $\left.\mathrm{m}\right)$; r: koefisien korelasi (coefficient of correlation); $\mathrm{R}^{2}$ : koefisien determinasi (coefficient of determination: \%); SR: simpangan relatif(relative deviation: \%); SA:simpangan agregatif(agregatif deviation:\%)

sehingga model terbaik ditentukan dengan pembobotan dari kriteria-kriteria yang ada. Hasil pembobotan menunjukkan model (4) sebagai model terbaik. Model ini mempunyai koefisien determinasi yang besar $\left(\mathrm{R}^{2}=83,1 \%\right)$ dan sisaan dugaan yang kecil. Model tersebut yakni Ln Volume $=-9,0589+(1,8958) *(\operatorname{Ln}($ Diameter $))+$ $(3747) *($ Ln(Tinggi $))$.

Penyusunan model-model penduga volume dengan menggunakan diameter (hasil pengukuran menggunakan S) dapat digunakan. Hal ini ditunjukkan oleh hasil pendugaan volume dengan menggunakan diameter sebagai peubah bebas maupun diameter dan tinggi sebagai peubah bebas memperoleh $\mathrm{R}^{2}$ yang tinggi $(>80 \%)$. Hasil penelitian ini didukung oleh penelitian lain pada beberapa jenis tanaman yakni Acacia mangium, Swietenia mahagoni, dan Gmelina arborea (Susanty et al., 2006). Hasil penelitian ini menunjukkan model-model penduga volume yang dihasilkan umumnya memiliki $\mathrm{R}^{2}$ lebih dari 70\% (Tabel 10).

Secara umum, penyusunan model penduga volume menggunakan pengukuran dia- meter secara langsung (destructive sampling) memperoleh $\mathrm{R}^{2}$ (koefisien determinasi) lebih besar dibandingkan dengan penggunaan diameter dengan pengukuran tidak langsung (Krisnawati dan Bustomi 2004; Siswanto et al., 2007; Qirom dan Lazuardi, 2007; Siswanto 2008). Rata-rata koefisien determinasi yang diperoleh lebih dari 90\% untuk beberapa jenis tanaman yakni: Peronema canescens Jack (Krisnawati dan Bustomi 2004); Tiomonius nitens (Siswanto et al. 2007); A. mangium (Qirom dan Lazuardi 2007); dan A. auriculiformis (Siswanto 2008).

\section{KESIMPULAN}

Penggunaan diameter sebagai peubah tunggal dapat digunakan untuk menyusun model penduga volume pohon baik volume total maupun volume merchantable. Namun demikian, penambahan variabel tinggi kedalam model tetap diperlukan. Model penduga volume pohon dengan dua variabel diameter dan tinggi digunakan untuk 
menyusun tabel volume standar. Panambahan variabel tinggi kedalam model hanya meningkatkan koefisien determinasi $<2 \%$. Model terbaik untuk menduga volume pohon mempunyai koefisien determinasi $\left(\mathrm{R}^{2}\right)$ yang tinggi $(>80 \%)$. Model terbaik untuk menduga volume pohon total yakni 1) menggunakan peubah diameter: Ln Volume = $-7,9444+(2,1952) *($ Ln(Diameter $)) ; 2)$ menggunakan peubah diameter dan tinggi: Volume $=$ $2,4081 * 10^{-4} *\left(\operatorname{Ln}\left(\text { Diameter }^{2} \text {.Tinggi }\right)^{0,80871}\right.$. Model terbaik untuk menduga volume pohon merchantable yakni 1) menggunakan peubah diameter: Ln Volume $=-8,2598+(2,2843) *(\operatorname{Ln}($ Diameter $))$ 2) menggunakan peubah diameter dan tinggi: Ln Volume $=-9,0589+(1,8958) *(\operatorname{Ln}($ Diameter $))+$ (Ln(Tinggi)). Penggunaan Spiegel Relaskop Bitterlich (SRB) untuk membantu mengukur diameter pohon pada ketinggian tertentu tanpa menebang pohon sampelnya dapat digunakan tetapi penggunaan alat tersebut harus dilakukan secara hatihati dan ketelitian yang tinggi dari pengukur. Penentuan jarak dan koreksi jarak pengukuran harus dilakukan dengan teliti karena konversi diameter dari pembacaan alat ini sangat tergantung nilai dari jarak yang digunakan.

\section{UCAPAN TERIMAKASIH}

Penulis mengucapkan terima kasih kepada Bapak Suyitno atas ijin menggunakan tanaman Jelutung Rawa sebagai obyek penelitian serta Edy Suryanto (Teknisi Litkayasa Balai Penelitian Kehutanan Banjarbaru) atas bantuannya dalam pengambilan data di lapangan.

\section{DAFTAR PUSTAKA}

Akinnifesi, F.K. and F.A. Akinsami. 1995. Linear Equation for Estimating the Merchantable Wood Volume of Gmelina arborea in Southwest Nigeria. Journal of Tropical Science1995: Volume 7 No. 3: 391-397

Bitterlich, W. 1990. A Comprehensive Concept of Tree and Stand Measurements. Proceedings from Session S4.01 Mensuration, Growth and Yield at the world congress of the IUFRO. Montreal, Canada. August 5-11. p 1 - 12. http://online. anu.edu.au/Forestry/mensuration/RELAKOP. HTM.
Brandies,T.J., M.D Delaney, B.R. Parresol, and L. Royer. 2006. Development of Equations for Predicting Puerto Rican Subtropical Dry Forest Biomass and volume. Forest Ecology and Management 233 (2006) 133-142.

Brown, S. and A.E. Lugo. 1992. Aboveground Biomass Estimate for Tropical Moist Forest of the Brazilian Amazon. Interciencia 17: 8 - 18.

Brown, S. 1997. Estimating Biomass and Biomass Change of Tropical Forest: a Primer. Rome, Italy: FAO Forestry Paper 134.

Draper, N. dan A. Smith. 1992. Analisis Regresi Terapan. (terjemahan). PT. Gramedia Pustaka. Jakarta.

Husch, B. 1963. Forest Mensuration and Statistics. The Roland Press Company. New York.

Krisnawati, H. dan S. Bustomi. 2004. Model Penduga Isi Pohon Bebas Cabang Jenis Sungkai (Peronema canescens Jack.) di KPH Banten. Bul. Pen. Hutan No. 644, 2004: 39 -50.

Onyekwelu, J.C., R. Mosandl and B. Stimm. 2006. Productivity, Site Evaluation and State of Nutrition of Gmelina arborea Plantations in Oluwa and Omo Forest Reserves, Nigeria. Forest Ecology and Management 229 (2006): 214-227.

Onyekwlu, J. C. 2005. Site Index Curves for Site Quality Assessment of Nauclea diderrichii Monoculture Plantations in Omo Forest Reserve, Nigeria. Journal of Tropical Forest Science 17(4): 532-542.

Peng, C. 2000. Growth and Yield Models for UnevenAged Stands: Past, Present and Future. Forest Ecology and Management 132 (2000): 259279

Philips, D., T.E. Brash, I. Yasman, P. Subagyo, and P.R. van Gardingen. 2003. An IndividualBased Spatially Explicit Tree Growth Model for Forests in East Kalimantan (Indonesian Borneo). Ecological Modelling 159(2003:) 1 - 26.

Qirom, M.A. dan D. Lazuardi. 2008. Model Persamaan Linear untuk Penduga Volume Pohon Hutan Tanaman Jenis Mangium di Kalimantan Selatan. Jurnal Penelitian Hutan Tanaman Vol.4 No.3: 119 - 187.

Siswanto, B.E., D. Wahjono, Harbagung dan R. Imanuddin. 2007. Ketepatgunaan berbagai Model Pendugaan Volume Pohon Jenis Kayu Sibu (Timoneus nitens M.ET.p) di Wilayah Kecamatan Mandobo, Kabupaten Merauke, Provinsi Papua. Jurnal Peneliti-an Hutan dan Konservasi Alam Vol IV (2): 291 - 299. 
Siswanto, B.E. dan R. Imanuddin. 2008. Persamaan Regresi Penaksiran Volume Pohon Sonokeling (Dalbergia latifolia Roxb) di Kediri, Jawa Timur. Info Hutan Vol. V No. 4: 289-298.

Siswanto, B.E. 2007. Model Pendugaan Isi Pohon Acacia auriculiformis A. Cunn di Kesatuan Pemangkuan Hutan Gundih, Jawa Tengah. Jurnal Penelitian Hutan Tanaman Vol.5 Suplemen (2): 279 - 290.

Siswanto, B.E. dan Harbagung. 2004. Persamaan Regresi Volume Pohon Jenis Acacia mangium Willd. di Daerah Sanggau, Kalimantan Barat Jurnal Penelitian Hutan dan Konservasi Alam Vol. 1(2) 2004: 129-138.

Spurr, S.H. 1952. Forest Inventory. The Ronald Press Company. United States of America.

Sturtevant, B.R. and S.W. Seagle. 2004. Comparing Estimates of Forest Site Quality in Old SecondGrowth Oak Forests. Forest Ecology and Management 191 (2004) 311-328.

Susanty, F.H., A. Supriyanto, M. Budiono dan D. Suprayitno. 2006. Analisis Model Pendugaan Volume Jenis Acacia mangium, Gmelina arborea, dan Swietenia mahagoni di Hutan Tanaman. Prosiding Seminar Bersama Hasil-hasil Penelitian Tanggal 12 April 2006. Samarinda.
Tewari, V.P., A. Verma, V.S. Kishan Kumar. 2002. Growth and Yield Function for Irrigated Plantation of Eucalyptus camaldulensis in The Hot Desert of India. Bioresource Technology 85(2002): 137 - 146.

Trasobares, A., M. Tome and J. Miina. 2004. Growth and Yield Model for Pinus halepensis Mill. In Catalonia, north-east Spain. Forest Ecology and Mangement 203 (2004): 49-62.

Turski, M, C. Beker, K. Kazmierczak and T. Najgrakowski. 2008. Allometric Equations for estimating the mass and volume of fresh assimilational apparatus of Standing Scots Pine (Pinus sylvestris L.) Trees. Forest Ecology and Management 255 (2008) 2678-2687.

Vanclay, J.K. 1994. Modelling Forest Growth and Yield: Applications to Mixed Tropical Forests. CAB International, Wallingford.

van Laar and A. Akca. 1997. Forest Mensuration. Cuvillier Verlag. Gottingen. 418p.

Walpole, R.E. 1995. Pengantar Statistika. Edisi ke -3. Gramedia Pustaka Utama.

Wang, Y. and B. Payandeh. 1995. A Base-Age Invariant Site Index Model for Aspen Stand in North Central Ontorio. Forest Ecology and Management 72 (1995) 207-211. 